\section{Temporal analysis of the relationship between dengue and meteorological variables in the city of Rio de Janeiro, Brazil, 2001-2009}

\author{
Análise temporal da relação entre dengue e \\ variáveis meteorológicas na cidade do Rio de \\ Janeiro, Brasil, no período de 2001 a 2009
}

Adriana Fagundes Gomes 1 Aline Araújo Nobre 2

Oswaldo Gonçalves Cruz 2

\footnotetext{
1 Escola Nacional de Saúde Pública Sergio Arouca, Fundação Oswaldo Cruz, Rio de Janeiro, Brasil.

2 Programa de Computação Científica, Fundação Oswaldo Cruz, Rio de Janeiro, Brasil.

Correspondence A. F. Gomes

Escola Nacional de Saúde Pública Sergio Arouca, Fundação Oswaldo Cruz. Rua Jorge Lossio 246, bloco 2, apto. 05, Rio de Janeiro, $R J$ 25961-265, Brasil. afagundesgomes@gmail.com
}

\begin{abstract}
Dengue, a reemerging disease, is one of the most important viral diseases transmitted by mosquitoes. Climate is considered an important factor in the temporal and spatial distribution of vector-transmitted diseases. This study examined the effect of seasonal factors and the relationship between climatic variables and dengue risk in the city of Rio de Janeiro, Brazil, from 2001 to 2009. Generalized linear models were used, with Poisson and negative binomial distributions. The best fitted model was the one with "minimum temperature" and "precipitation", both lagged by one month, controlled for "year". In that model, a $1{ }^{\circ} \mathrm{C}$ increase in a month's minimum temperature led to a $45 \%$ increase in dengue cases in the following month, while a 10-millimeter rise in precipitation led to a $6 \%$ increase in dengue cases in the following month. Dengue transmission involves many factors: although still not fully understood, climate is a critical factor, since it facilitates analysis of the risk of epidemics.
\end{abstract}

Dengue; Climate; Temporal Distribution

\section{Introduction}

Dengue is an acute febrile disease caused by arboviruses (arthropod-borne viruses) of the Flaviviridae family, with female Aedes aegypti culicid mosquitoes as the vector. Tropical countries are the most heavily affected due to their environmental, climatic, and social conditions. Climate is an important factor in the temporal and spatial distribution of vector-transmitted diseases like dengue fever. Studies of climatic variables can improve knowledge and prediction of epidemic seasonality 1 , because the vector-climate relationship is just as important as vector-human interaction.

Several authors have investigated the relationship between climatic variables and dengue fever, often using time-series analysis to describe temporal trends, to identify patterns, and even to make predictions. The variables used in these studies have been temperature, precipitation, relative humidity, wind velocity, and El Niño Southern Oscillation (ENSO) 2,3,4,5,6,7,8. Studies have also evaluated dengue's relationship with socio-demographic and environmental variables in the municipality of Rio de Janeiro, Brazil, with a view to examining the effect of seasonal and annual factors on increases and decreases in dengue cases, as well as to make predictions 9,10,11,12

Dengue incidence fluctuates with climatic conditions and is associated with increased tem- 
perature and rainfall ${ }^{13}$. Such conditions favor an increase in the number of available breeding sites, as well as the vector's development, and thereby increase the probability of vector-human (and consequently human-virus) interaction. According to various studies, temperature has an impact on the population size, maturation period, blood-sucking activity, and survival rate of Ae. aegypti 14,15,16,17. The relationship to precipitation depends on local characteristics and whether breeding sites are maintained predominantly by rain ${ }^{3}$.

Dengue is expected to be an important public health problem for many years, due to population growth and movement, disorderly urban development, deficient water supply and inappropriate public waste disposal, proliferation of vector breeding sites, and lack of an effective vaccine 18,19. Programs to prevent the disease concentrate on developing early intervention systems. Such systems require parameters that can predict the risk of epidemics. The climatic model offers advantages, as a low-cost system based on collecting meteorological data. The current study aimed to examine the effect of seasonal factors and how the climatic variables "temperature" and "precipitation" were related to dengue fever risk in the city of Rio de Janeiro from 2001 to 2009.

\section{Methodology}

The study followed an analytical ecological design aimed at assessing the relationship between dengue risk and the climatic variables "temperature" and "precipitation" in the municipality of Rio de Janeiro. Rio de Janeiro is located in Southeast Brazil at $23^{\circ} 04^{\prime} 10^{\prime \prime}$ latitude South and $43^{\circ} 47^{\prime} 40^{\prime \prime}$ longitude West. The city has an estimated population of 6,093,472 and area of 1,224.56 $\mathrm{km}^{2}$. The climate is Atlantic Tropical, characterized by a mean annual temperature of $23^{\circ} \mathrm{C}$ and narrow temperature range. Average annual precipitation is about $1,000 \mathrm{~mm}$, with most rainfall from December to March.

Monthly notifications of dengue cases are available by neighborhood of residence on the portal of the Rio de Janeiro City Health Department (Secretaria Municipal de Saúde - SMS-RJ). Temperature data were obtained from the Weather Forecasting Center of the National Space Research Institute (Instituto Nacional de Pesquisas Espaciais - INPE), which draws its data from four monitoring stations, only one of which was used, since it offers complete data for the study period. Rainfall data, available on the portal of the Municipal Department of Public Works (Secretaria Municipal de Obras Públicas), were taken from
32 monitoring stations (Figure 1). For this study, cases were spatially aggregated, i.e., all cases in all neighborhoods were totaled by month from 2001 to 2009.

Exploratory data analysis was performed using boxplots, histograms, time series decomposition, and auto-correlation graphics. The outcome variable was the number of dengue cases, and the independent variables were the mean monthly precipitation at the 32 stations and the mean, low, and high monthly temperatures. After exploratory analysis, cutoff points for mean temperature were evaluated using generalized additive models 20 . Dengue risk was observed to increase up to $26^{\circ} \mathrm{C}$. According to the literature, the mosquito's optimal temperature is from $22^{\circ} \mathrm{C}$ to $26^{\circ} \mathrm{C}$, based on which the following variables were used: proportion of days in the month with mean temperature below $22^{\circ} \mathrm{C}$, proportion of days in the month with mean temperature from $22^{\circ} \mathrm{C}$ to $26^{\circ} \mathrm{C}$, and proportion of days in the month with mean temperature above $26^{\circ} \mathrm{C}$.

The effect of climatic variables on the reported number of cases was evaluated using generalized linear models 21 , with a logarithmic link function for Poisson and negative binomial distribution. Time series are characterized by a sequence of data obtained at equal time intervals. The data used here refer to months, which do not have the same number of days, so that an offset was employed in multiplying the population by the number of days in the month. Model fit was evaluated by auto-correlation and normality test of residuals.

The analyses were performed using the $\mathrm{R}$ program, version 2.10.1 (The R Foundation for Statistical Computing, Vienna, Austria; http:// www.r-project.org). The models were compared with the Akaike Information Criterion (AIC), which is widely used to compare nested and non-nested models. This criterion is calculated using the log-likelihood penalized by the number of parameters in the model. For models with the same dataset, the best model is the one with the lowest AIC 22.

\section{Results}

The only non-epidemic years during the study period were 2003 to 2005 . The highest number of cases occurred during the 2001-2002 epidemic, reaching 52,861 in March 2002. Figure 2 shows the time series for the variables: number of dengue cases; mean, maximum, and minimum temperatures; precipitation; and proportions of days in the month with mean temperature below $22^{\circ} \mathrm{C}$, from $22^{\circ} \mathrm{C}$ to $26^{\circ} \mathrm{C}$, and above $26^{\circ} \mathrm{C}$. 

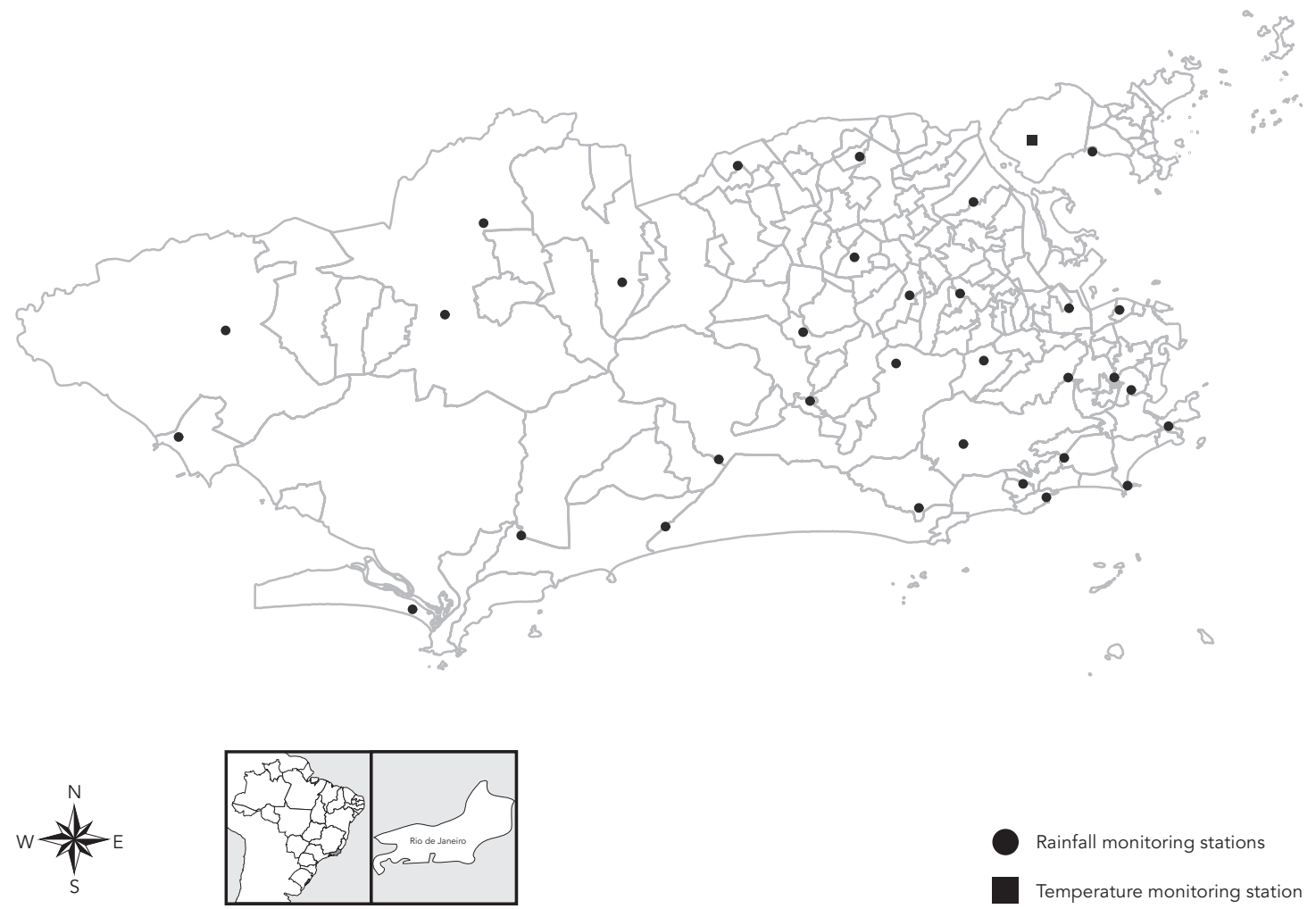

Rainfall monitoring stations

Temperature monitoring station

Analysis of case distribution showed that most cases were concentrated in the first half of the year, mainly in March, April, and May, underlining the known seasonality of dengue fever. Mean annual temperatures for the period were $24^{\circ} \mathrm{C}$ for monthly mean temperature, $21^{\circ} \mathrm{C}$ for monthly minimum temperature, and $29^{\circ} \mathrm{C}$ for monthly maximum temperature. Monthly accumulated precipitation in the period ranged from 6 to $371 \mathrm{~mm}$.

Since the data present over-dispersion (sample mean of 3,108 and sample variance of 84,695,150), comparison of the models' AIC showed that negative binomial distribution was a better choice than Poisson distribution. Models were initially fitted with only one variable; in these, the variable "proportion of days with temperature from $22^{\circ} \mathrm{C}$ to $26^{\circ} \mathrm{C}$ " was not significant, even when lagged, while precipitation was only significant in relation to the number of cases when lagged by one month. The other variables were significant with lags of up to two months.
On the basis of this initial analysis, all the models contained the variable precipitation, and then the inclusion of temperature-related variables was evaluated. Residuals analysis of the models showed that a time structure persisted; accordingly, an annual effect was incorporated into the model. Introduction of this variable improved both auto-correlation of residuals and model fit.

Table 1 shows the estimated relative risk (RR), 95\% confidence intervals (95\%CI), and AIC for the fitted models. The RR for the variable "precipitation" varies little between the models. Concerning the AIC criterion for comparing models, the model with the best fit was the one which (after controlling for the variable "year") used the variables "minimum temperature" and "precipitation", both lagged by one month. In that model, a one-degree rise in temperature in a month led to a $45 \%$ increase in dengue cases in the following month, while a $10 \mathrm{~mm}$ increase in precipitation led to a $6 \%$ increase in dengue cases in the following month. Models with the variables "mean 
2a) Dengue cases

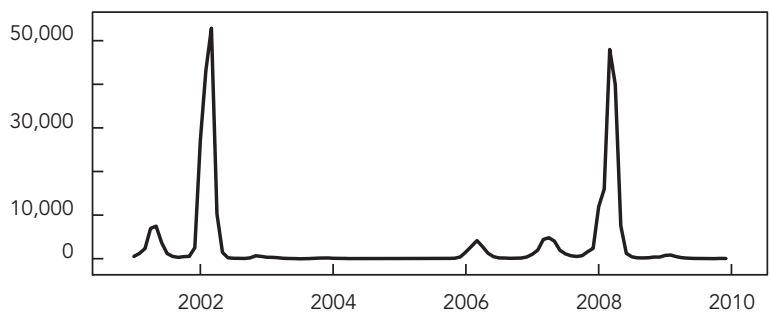

2c) Maximum, mean, and minimum temperature $\left({ }^{\circ} \mathrm{C}\right)$

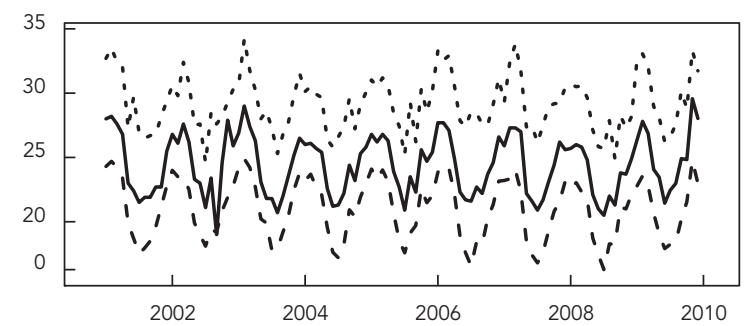

2e) Rainfall ( $\mathrm{mm}$ )

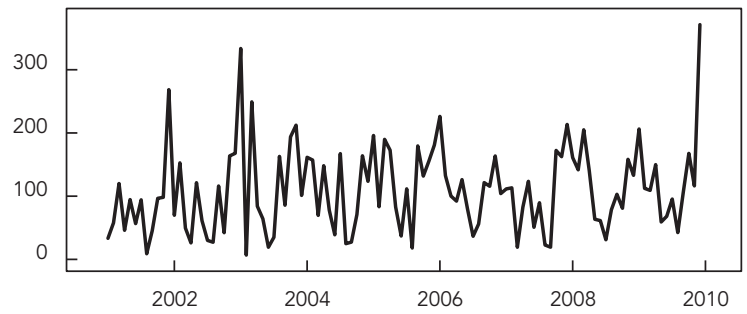

2b) Proportion of days with mean temperature below $22^{\circ} \mathrm{C}$

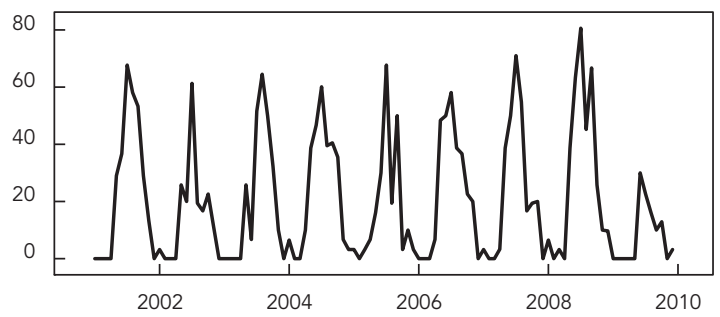

2d) Proportion of days with mean temperature from $22^{\circ} \mathrm{C}$ to $26^{\circ} \mathrm{C}$

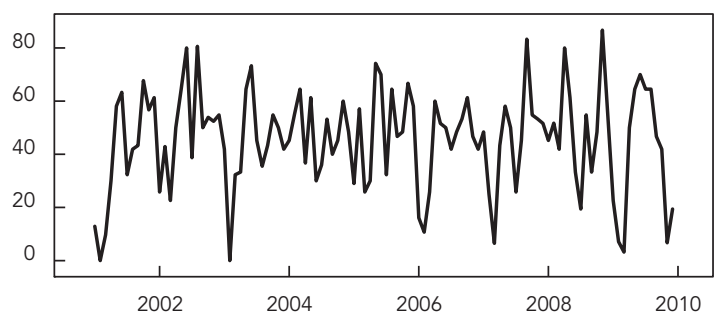

2f) Proportion of days with mean temperature above $26^{\circ} \mathrm{C}$

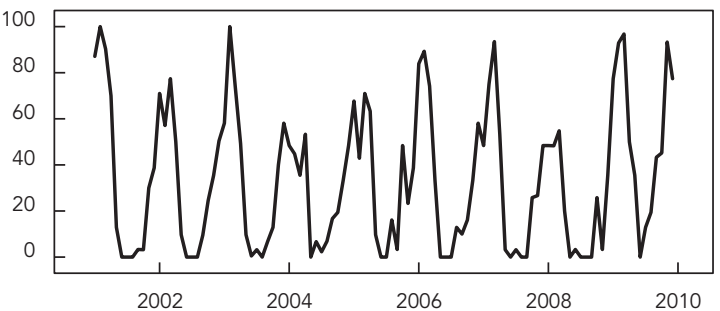

temperature" and "maximum temperature" presented similar results.

Figure 3 shows the coefficients for the variable "year" in Model 1: 2002 and 2008 were the only years in which the effect was greater than in 2001, which was taken as baseline. They were the years in the study period with the most cases, but this variable was not statistically significant. Figure 4 shows the time series for dengue cases and the series as estimated by Model 1, which managed to detect the epidemic years, although underestimating the major epidemics and over- estimating the number of dengue cases in the following year.

\section{Discussion}

Several studies have reported a positive association between minimum temperature lagged by one month and dengue incidence 3,4,12,23,24 . Minimum temperature is thus a critical limiting factor in the development and maintenance of the vector population. Replication of the virus 
Table 1

Relative risk (RR), 95\% confidence intervals $(95 \% \mathrm{Cl})$, and Akaike Information Criterion (AIC) of the proposed models for the relationship between dengue transmission and meteorological variables. Rio de Janeiro, Brazil, 2001-2009.

\begin{tabular}{|c|c|c|c|}
\hline Models/Variables lagged by 1 month & RR & $95 \% \mathrm{Cl}$ & AIC \\
\hline \multicolumn{4}{|l|}{1} \\
\hline Minimum temperature & 1.452 & $1.338-1.576$ & 1,568 \\
\hline Precipitation & 1.006 & $1.003-1.009$ & \\
\hline \multicolumn{4}{|l|}{2} \\
\hline \multirow[t]{2}{*}{ Proportion of days with temperature $>26^{\circ} \mathrm{C}$} & 1.092 & 1.068-1.115 & 1,577 \\
\hline & 1.008 & $1.005-1.011$ & \\
\hline \multicolumn{4}{|l|}{3} \\
\hline Proportion of days with temperature $<22^{\circ} \mathrm{C}$ & 0.894 & $0.867-0.921$ & 1,584 \\
\hline Precipitation & 1.007 & $1.003-1.010$ & \\
\hline
\end{tabular}

Note: all models were controlled for variables indicating the year.

Figure 3

Estimated coefficients of variables indicating the year in Model 1.

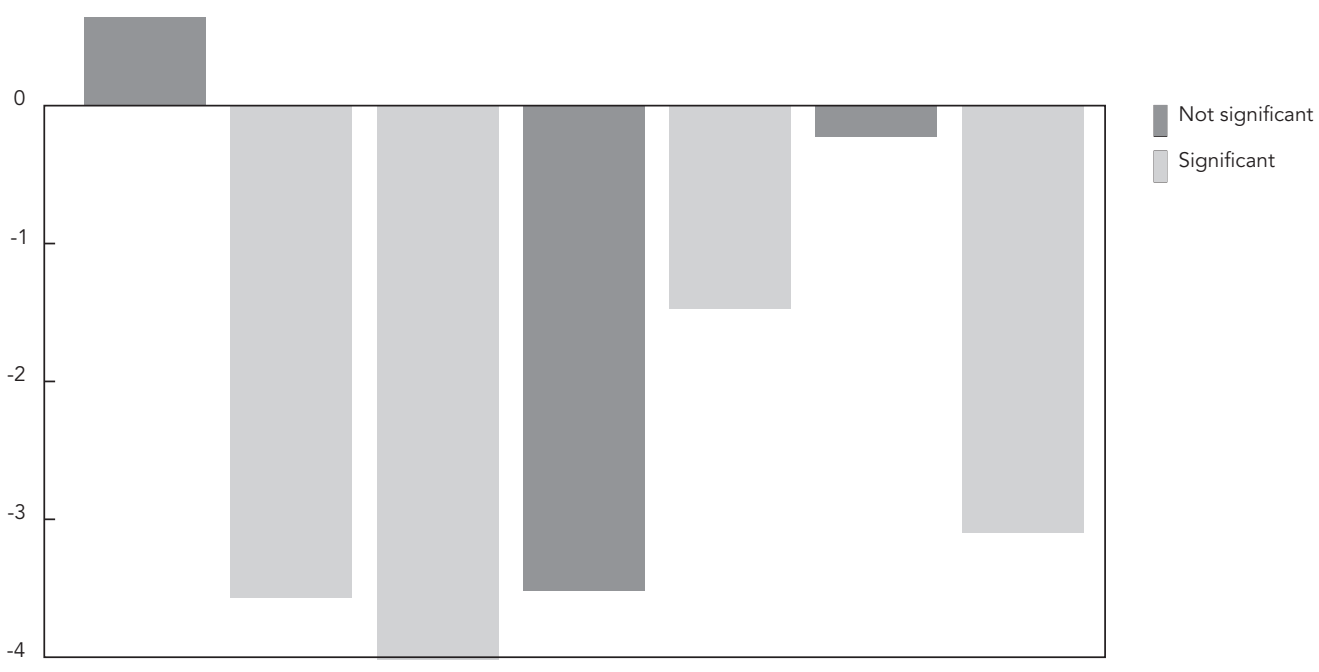

and maturation periods in the insect (extrinsic period) are shortened by increased temperature $25,26,27$, while decreased virus incubation time increases the likelihood that the vector will live long enough to transmit the virus, significantly boosting the magnitude of the epidemics. Studies have shown that Ae. aegypti, the vector for dengue in the Americas, ceases to feed when temperature falls below $17^{\circ} \mathrm{C}$, and that the virus is not amplified in the vector when temperature falls below $18^{\circ} \mathrm{C}$, while the threshold survival temperature for the dengue virus has been estimated at $11.9^{\circ} \mathrm{C}$ $25,28,29$. Thus, at very low temperatures the virus develops more slowly, and the mosquito does not live long enough to become infectious and transmit the virus 30 . Accordingly, analysis of minimum temperatures affords a better understanding of dengue epidemics. This study showed a small (but significant) coefficient for the relationship between dengue cases and precipitation. Studies 


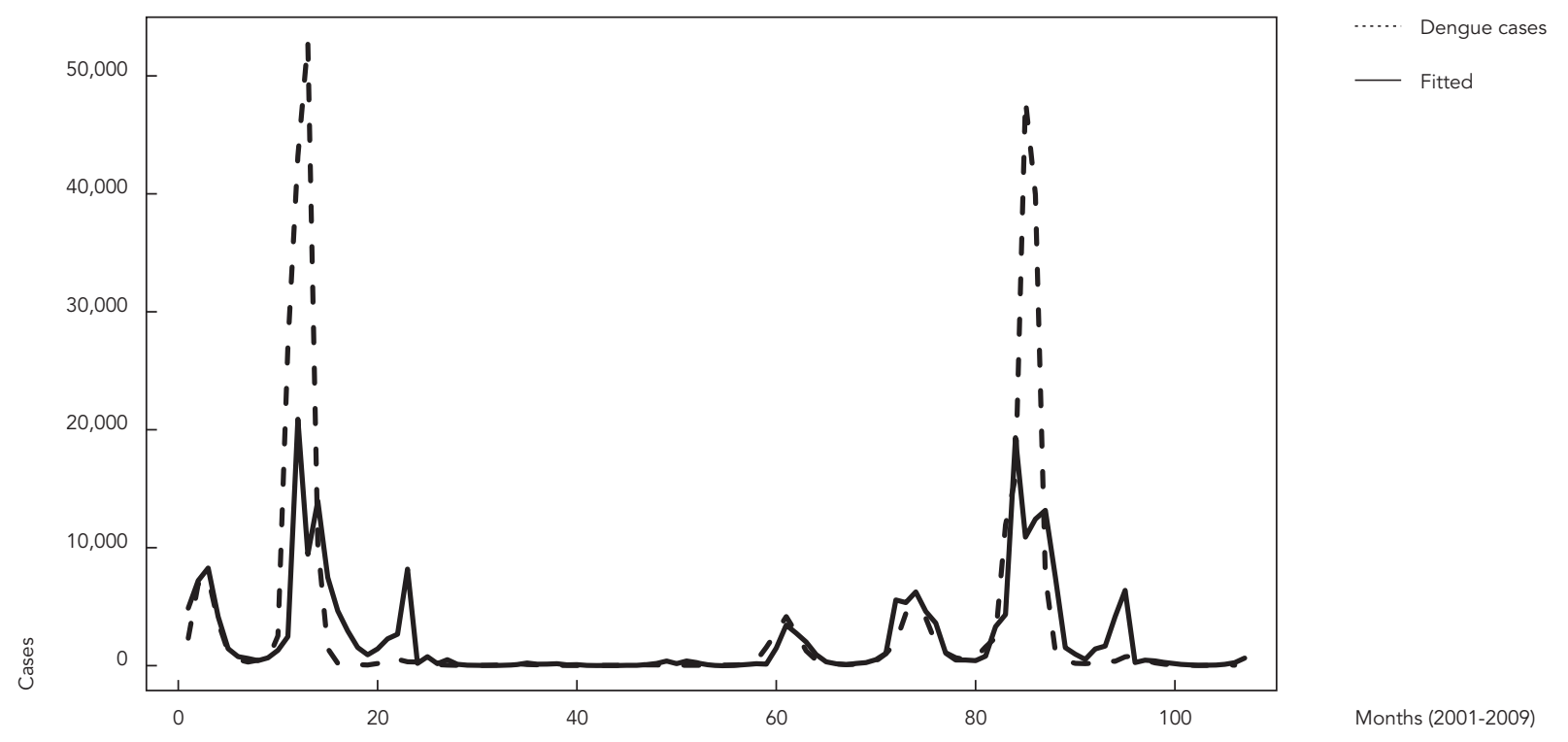

in the literature on the correlation between rainfall and dengue are contradictory, because the relationship depends on local characteristics 3,31 .

Analysis of Model 3 shows that a unit increase in the proportion of days in the month when the mean temperature falls below $22^{\circ} \mathrm{C}$ led to an $11 \%$ decrease in the number of dengue cases in the following month, corroborating reports by other authors, because the vector's feeding rate declines at lower temperatures (as does the viral transmission rate, consequently) 31,32 .

A study by Honório et al. 32 in three neighborhoods in the city of Rio de Janeiro shows that air temperature from $22^{\circ} \mathrm{C}$ to $24^{\circ} \mathrm{C}$ has a positive impact on the development of Ae. aegypti, while temperatures above $24^{\circ} \mathrm{C}$ produce no evident effect. In the present study, that temperature range was incorporated into the variable "proportion of days in the month with mean temperature from $24^{\circ} \mathrm{C}$ to $26^{\circ} \mathrm{C}$, which was not statistically significant.

According to Model 2, which incorporates temperature above $26^{\circ} \mathrm{C}$, a unit increase in the proportion of days in the month when mean temperature is above $26^{\circ} \mathrm{C}$ leads to a $9.2 \%$ increase in dengue cases in the following month. That result was expected, because studies have found an association between dengue risk and temperatures above $26^{\circ} \mathrm{C}$, with temperatures from $21^{\circ} \mathrm{C}$ to $29^{\circ} \mathrm{C}$ favoring the development of Ae. aegypti, and from $22^{\circ} \mathrm{C}$ to $30^{\circ} \mathrm{C}$, the longevity and fertility of the adults 2,33 .

The complexity of dengue transmission dynamics has prompted studies on various factors that contribute to circulation of the virus. Although the current study emphasizes the impact of climate, other approaches beyond socio-environmental conditions must be considered. One limitation of this study was the use of reported dengue cases, which fail to represent total dengue cases. These numbers may underestimate true incidence 34,35 . Another limitation was the lack of reliable information in each time period on the specific incidence rates for each serotype (among the circulating serotypes) 36 . Some authors claim that the entry of a new serotype into a non-immune population entails a risk of explosive epidemics, even while the succession of serotypes can result in epidemics with more severe cases 10,18,37. The role of the exposed human populations, the effect of immunity to the virus in the at-risk population, and infestation by the mosquito vector are decisive factors in maintaining the virus in circulation. 


\section{Conclusion}

Dengue transmission involves numerous factors, including the impact of climate, whose role is still not fully understood. Elucidating the role of climate is critical, because it facilitates analysis of the risk of epidemics and assists preventive ef- forts. This study proposed a model for examining the time series of dengue fever by which mean, maximum, and minimum temperature and precipitation were associated statistically with the number of cases, while one month-lagged minimum temperature proved to be the strongest explanatory factor for the number of dengue cases.

\section{Resumo}

A dengue é doença reemergente e uma das mais importantes doenças virais transmitida por mosquito. $O$ clima é considerado um fator relevante na distribuição temporal e espacial das doenças transmitidas por vetores. O objetivo deste trabalho foi estudar o efeito de fatores sazonais e a relação entre as variáveis climáticas e o risco de dengue, na cidade do Rio de Janeiro, Brasil, entre 2001 e 2009. Foram utilizados modelos lineares generalizados, com distribuição Poisson e binomial negativa. O modelo com melhor ajuste fo $i$ o controlado por variáveis indicadoras do ano, que apresentou as variáveis temperatura mínima e precipitação, ambas com defasagem de um mês. Nesse modelo, o aumento de um grau na temperatura mínima em um mês leva ao aumento de 45\% no número de casos de dengue no mês seguinte, enquanto o aumento em 10 milímetros na precipitação leva ao aumento de 6\% no número de casos de dengue no mês seguinte. A transmissão da dengue está relacionada a muitos fatores; o impacto do clima, apesar de ainda não ser bem entendido, é apontado como crítico ao facilitar análise de risco de epidemias.

Dengue; Clima; Distribuição Temporal

\section{Contributors}

A. F. Gomes participated in the data analysis and interpretation and wrote the article. A. A. Nobre collaborated in the interpretation of the data and critical revision of the manuscript. O. G. Cruz contributed to the critical revision of the manuscript. 


\section{References}

1. Rosa-Freitas MG, Schreiber KV, Tsouris P, Weimann ETS, Luitgards-Moura JF. Associations between dengue and combinations of weather factors in a city in the Brazilian Amazon. Rev Panam Salud Pública 2006; 20:256-67.

2. Hii YL, Rocklöv J, Ng N, Tang CS, Pang FY, Sauerborn R. Climate variability and increase in intensity and magnitude of dengue incidence in Singapore. Glob Health Action 2009; 2.

3. Wu PC, Guo HR, Lung SC, Lin CY, Su HJ. Weather as an effective predictor for occurrence of dengue fever in Taiwan. Acta Trop 2007; 103:50-7.

4. Liang L, Hualiang L, Linwei T, Weizhong Y, Jimin S, Qiyong L. Time series analysis of dengue fever and weather in Guangzhou, China. BMC Public Health 2009; 9:395.

5. Gasparrini A, Armstrong B. Time series analysis on the health effects of temperature: advancements and limitations. Envirol Res 2010; 110:633-8.

6. Thail, KTD, Anders KL. The role of climate variability and change in the transmission dynamics and geographic distribution of dengue. Exp Biol Med 2011; 236:944-54.

7. Earnest A, Tan SB, Wilder-Smith A. Meteorological factors and El Niño Southern Oscillation are independently associated with dengue infections. Epidemiol Infect 2012; 140:1244-51.

8. Cassab A, Morales V, Mattar S. Factores climáticos y casos de dengue en Montería, Colombia, 2003 2008. Rev Salud Pública 2011; 13:115-28.

9. Ferreira GS. Análise espaço-temporal da distribuição dos casos de dengue na cidade do Rio de Janeiro no período de 1986 a 2002 [Masters Thesis]. Rio de Janeiro: Universidade Federal do Rio de Janeiro; 2004.

10. Teixeira TRA. Análise espacial e temporal da dengue no contexto sócio-ambiental do Município do Rio de Janeiro, 1996-2006 [Masters Thesis]. Rio de Janeiro: Escola Nacional de Saúde Pública Sergio Arouca, Fundação Oswaldo Cruz; 2009.

11. Luz PM, Mendes BVM, Codeco CT, Struchiner CJ, Galvani AP. Time series analysis of dengue incidence in Rio de Janeiro, Brazil. Am J Trop Med Hyg 2008; 79:933-9.

12. Descloux E, Mangeas M, Menkes CE, Lengaigne $M$, Leroy A, Tehei T, et al. Climate-based models for understanding and forecasting dengue epidemics. PLoS Negl Trop Dis 2012; 6:e1470.

13. Ribeiro AF, Marques G, Voltolini JC, Condino MLF. Associação entre incidência de dengue e variáveis climáticas. Rev Saúde Pública 2006; 40:671-6.

14. Halstead SB. Dengue. Lancet 2007; 370:1644-52.

15. Jetten TH, Focks DA. Potential changes in the distribution of dengue transmission under climate warming. Am J Trop Med Hyg 1997; 57:285-97.

16. Li CF, Lim TW, Han LL, Fang R. Rainfall, abundance of Aedes aegypti and dengue infection in Selangor, Malaysia. Southeast Asian J Trop Med Public Health 1985; 16:560-8.
17. Chen SC, Hsieh MH. Modeling the transmission dynamics of dengue fever: implications of temperature effects. Sci Total Environ 2012; 431:385-91.

18. World Health Organization. Dengue haemorrhagic fever: diagnosis, treatment, prevention and control. 2nd Ed. Geneva: World Health Organization; 1997.

19. Holmes EC, Twiddy SS. The origin, emergence and evolutionary genetics of dengue virus. Infect Genet Evol 2003; 3:19-28.

20. Wood SN. Generalized additive models: an introduction with R. Boca Raton: Chapman \& Hall/ CRC; 2006.

21. McCullagh P, Nelder JA. Generalized linear models. London: Chapman and Hall; 1989.

22. Akaike H. A new look at the statistical model identification. IEEE Trans Automat Contr 1974; 19: 716-23.

23. Hurtado-Díaz M, Riojas-Rodríguez H, Rothenberg SJ, Gomez-Dantés H, Cifuentes E. Short communication: impact of climate variability on the in cidence of dengue in Mexico. Trop Med Int Health 2007; 12:1327-37.

24. Yasuno M, Tonn RJ. A study of biting habits of Aedes aegypti in Bangkok, Thailand. Bull World Health Organ 1970; 43:319-25.

25. Watts DM, Burke DS, Harrison BA, Whitmire RE, Nisalak A. Effect of temperature on the vector efficiency of Aedes aegypti for dengue 2 virus. Am J Trop Med Hyg 1987; 36:143-52.

26. Mendonça M. Febre amarela silvestre. Rio de Janeiro: Gráfica Olympia; 1941.

27. Reiter P. Global warming and mosquito-borne disease in USA. Lancet 1996; 348:622.

28. Reed W, Carroll J, Agramonte A. Experimental yellow fever, 1901. Mil Med 2001; 166(9 Suppl):55-60.

29. Christy JR, Clarke RA, Gruza GV, Jouzel J, Mann ME, Oerlemans J, et al. Observed climate variability and change. In: McCarthy JJ, Canziani OF, Leary NA, Dokken DJ, White KS, editors. Climate change 2001: impacts, adaptation, and vulnerability. Cambridge: Cambridge University Press; 2001. p. 99-181.

30. Hales S, de Wet N, Maindonald J, Woodward A. Potential effect of population and climate changes on global distribution of dengue fever: an empirical model. Lancet 2002; 360:830-4.

31. Gubler DJ, Reiter P, Ebi KL, Yap W, Nasci R, Patz JA. Climate variability and change in the United States: potential impacts on vector- and rodentborne diseases. Environ Health Perspect 2001; 109 Suppl 2:223-33.

32. Honório NA, Codeço CT, Alves FC, Magalhães M. Temporal distribution of Aedes aegypti in different districts of Rio de Janeiro, Brazil, measured by two types of traps. J Med Entomol 2009; 46:1001-14. 
33. Beserra EB, Castro Júnior FP, Santos JW, Santos TS, Fernandes CRM. Biologia e exigências térmicas de Aedes aegypti (L.) (Diptera:Culicidae) provenientes de quatro regiões bioclimáticas da Paraíba. Neotrop Entomol 2006; 35:853-60.

34. Phuong HL, de Vries PJ, Nagelkerke N, Giao PT, Hung le Q, Binh TQ, et al. Acute undifferentiated fever in Binh Thuan province, Vietnam: imprecise clinical diagnosis and irrational pharmacotherapy. Trop Med Int Health 2006; 11:869-79.

35. Thai KTD, Cazelles B, Nguyen NV, Vo LT, Boni MF, Farrar J, et al. Dengue dynamics in Binh Thuan province, southern Vietnam: periodicity, synchronicity and climate variability. PLoS Negl Trop Dis 2010; 4:e474.
36. Nogueira RMR, Araújo JMG, Schatzmayr HG. Dengue viruses in Brazil, 1986-2006. Rev Panam Salud Pública 2007; 22:358-63.

37. Nogueira RMR, Eppinghaus ALF. Dengue virus type 4 arrives in the state of Rio de Janeiro: a challenge for epidemiological surveillance and control. Mem Inst Oswaldo Cruz 2011; 106:255-6.

Submitted on $03 /$ Jan/2012

Final version resubmitted on 18/Jul/2012

Approved on 17/Aug/2012 
